Angels and Earthly Creatures 
THE MIDDLE AGES SERIES

Ruth Mazo Karras, Series Editor

Edward Peters, Founding Editor

A complete list of books in the series

is available from the publisher. 


\title{
Angels and Earthly Creatures
}

\author{
Preaching, Performance, and \\ Gender in the Later Middle Ages
}

\author{
Claire M. Waters
}

\section{$\overline{\text { PENN }}$}

UNIVERSITY OF PENNSYLVANIA PRESS

Philadelphia 
Copyright (C) 2004 University of Pennsylvania Press

All rights reserved

Printed in the United States of America on acid-frec paper

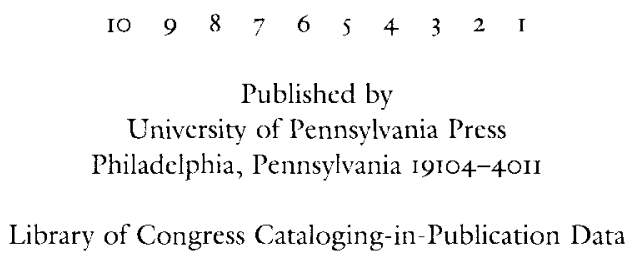

Library of Congress Cataloging-in-Publication Data

\section{Waters, Claire $M$.}

Angels and earthly creatures : preaching, performance, and gender in the later Middle Ages / Claire M. Waters.

p. cm. - (Middlc Ages series)

Includes bibliographical references and index.

ISBN 0-8122-3753-6 (cloth : alk. paper)

I. Preaching-History-Middlc Ages, 600-1500. 2. Rhetoric-Religious aspectsChristianity-History. 3. Rhetoric, Medieval. 4. Pastoral theology-Catholic ChurchHistory of doctrines-Middle Ages, 600-1500. I. Title. II. Scries.

$\mathrm{BV}_{4207} \cdot \mathrm{W}_{3} 82003$

25I:.0094'0902-dc22 
For my parents 
